\title{
Review on Potentials Resources and Challenges for Community Based Ecotourism Development in Ethiopia
}

\author{
Habib Bati Geda \\ Department of Ecotourism and Biodiversity conservations \\ Mettu University, P.O.Box ,318, Bedele,Ethiopia
}

\begin{abstract}
Ecotourism is defined as responsible travel to natural areas that conserve the environment and improves the wellbeing of local community. Community-based ecotourism (CBE) is a form of ecotourism in which the community has substantial control over it, and the majority of the benefits remain in the community. Ethiopia is a country having enormous potential of ecotourism resource including cultural, historical, archaeological and natural resources which are ideal for the development of sustainable community-based ecotourism projects. There are some community-based ecotourism initiatives in different parts of the country such as Adaba -Dodola, Semen Mountains National Park, Wonchi Crater Lake and Adwa. The objective of this review paper was to examine the challenges and potentials for Community Based Ecotourism development in Ethiopia. The findings from this review showed that, Lack of cooperation among stakeholders conflicts of interest over resource usage and a severe lack of trained manpower in tourism professions as being the major obstacles that hinders community-based ecotourism development in Ethiopia.
\end{abstract}

Keywords: Challenges, Potentials, community-based ecotourism, Ethiopia.

DOI: $10.7176 / \mathrm{JTHS} / 49-01$

Publication date:May $31^{\text {st }} 2020$

\section{INTRODUCTIONS}

\subsection{Background information}

Tourism is one of the largest and fastest growing industries in the world. It is an increasingly important source of income, employment and wealth in many countries. International tourism now accounts for a larger share of foreign exchange receipts and export earnings than any other industry in the world. The contribution of tourism industry to the global economy has grown fast in recent years. It has become one of the leading foreign exchange earnings for many countries (UN, 2001). (The International Ecotourism Society ,2012) has described Ecotourism as responsible travel to natural areas that protect the environment and enhance the welfare of local communities. In line with this, ( IUCN, 1994) defined the term ecotourism as an environmentally responsible travel and visitation to natural places, to experience and admire nature (and any related cultural features, both ancient and contemporary) which encourage conservation, and have a minimal visitor impact and provide active socio-economic involvement of local peoples, leading to their regional sustainability enhancement.

Community-based ecotourism (CBE) is a form of ecotourism in which the community has substantial control over it, and the majority of the benefits remain in the community. It has thus emerged as a valuable tool for poverty alleviation, wildlife conservation and the delivery of responsible and sustainable tourism offerings (Denman, 2001). Ethiopia is a country having enormous potential of ecotourism resource including cultural, historical, archaeological and natural resources which are ideal for the development of sustainable ecotourism ventures (Ketema, 2015). There are some encouraging community based ecotourism developments in Ethiopia such as Adaba-Dodola, a pilot ecotourism project on Semen Mountains National Park, Wonchi Crater Lake (near Ambo, Oromia Region), Adwa (Tigray region) and Mekit in north Wollo (Amahara region). The challenges facing the tourism industry are complex and numerous. Since, tourism sector is very recent, most of the local communities are not aware of about its economic, social, cultural and environmental benefits. As a result, some of the members of local community do not support community-based ecotourism projects. Community based projects have failed, usually because of lack of financial viability (Mitchell and Muckosy, 2008). It is still rare to find examples where projects are initiated, planned or managed by forces outside the community. On the other hand, when the NGOs fully implement the project and hands over management to the community, the project can easily fail because there has not been either initial or sustained support on the part of the community.(Hip well 2007) reported that involving local community in planning the project makes the community develop sense of ownership which is a guaranty for the success of that project. In line with this (Sewnet,2017) revealed that lack of basic ecotourism infrastructure and facilities, conflicts of interest over resource usage and a lack of trained man power are the major hindrances of community-based ecotourism development in Ethiopia.

\subsection{Objectives of the review}

$\checkmark$ To identify the potential resources for community-based ecotourism development in Ethiopia. 
$\checkmark \quad$ To Identify the challenges of community-based ecotourism development in Ethiopia

$\checkmark$ To show the trends of tourism development in different regimes of Ethiopia

\section{CONCEPT AND DEFINITIONS OF TOURISM}

Nature tourism is a form of tourism where the motivation of visitors centers on the observation of nature. However, ecotourism is a form of tourism that seek to minimize the negative and enhance the positive impacts of nature tourism (UN, 2001). Ecotourism is the responsible travel to natural areas that conserves the environment and improve the well-being of local people, it is distinguished from nature tourism as it involves travel to natural areas, provide benefit to the community and area visited, minimize the negative impacts of mass tourism, builds environmental awareness and respects local culture. It provides financial benefits for conservation and empowerment for local people. It allows local community to participate in decision making and provide alternative means of income and employment for local communities (UN, 2001; Neto, 2002; Kiss and Lowmen, 2004; Baker, 2008 and IES, 2010).

Community-based ecotourism is specific form of tourism where the local community has substantial control over, involvement in its development and management. As a result, most benefits remain within the community,Community based ecotourism should promote sustainable use and collective responsibility.It is environmentally responsible travel and visitation to relatively undisturbed natural areas and local communities in order to enjoy,study and appreciate nature and any associated cultural features tangible and intangible heritage, that promotes conservation, having low visitor impact, and provides for beneficially active socio economic involvement of local peoples (IUCN, 1996). Community based ecotourism establishments emphasize on empowering local communities to conserve natural resources and participate in their own economic development without control by external participants. Community based ecotourism can bring numerous socioeconomic benefits to a country or a locality, in terms of generating foreign exchange, creating local employment, motivating national and local economies, and fostering international peace and increased environmental awareness and education. But appropriate management structures and adequate planning, are required to ensure its sustainability (WWF, 2001).

\subsection{History of Tourism Development in Ethiopia}

The history of tourism is one of the unnoticed themes in Ethiopian history which has received less attention. In Ethiopia, the development of modern tourism as an important economic sector goes back to the imperial regime, when the Ethiopian Tourist Organization (ETO) was founded in 1961. Since that period, until the overthrow of the regime in 1974, the development of tourism has shown a remarkable trend in the arrival of tourists, an increase in the number of tourist arrivals from 19,215 in 1963 to 73,662 in 1973, were seen during the imperial regime. After the imperial regime had been overthrown from power in 1974, a military group (known as the Derg hold power). Recognizing the importance of tourism in the country's economy, the government has made possible efforts that would enable the enhancement of the sector. However, it was not long lasting due to some inter-related factors. This was due to tourism development in this period has been increasingly challenged by war, stressed political and diplomatic relations with the western world, new political and economic reforms, restriction on free entry of tourists, drought/famine, and government change. On the other hand, the outbreak of political disorder, civic war, and famine has always been followed by the frequent and instant dissemination of the news in western media which led to any warning on the anticipated incidents and immediate ca + ncellations of trips by international tourists and due to security reasons, tourists might perhaps forced to abandon their intention of visiting tourist attractions which are unsafe. Such unfavorable environment limits pleasure and relaxation that the tourists want and restricts tourists' comfort, who had the choice of travelling to other safe countries. In that period flow of tourists gradually decreased from 50,220 in 1974 to 28,984 in 1977 and a fall from 22.2 million birr in 1974 to 3.3 million birr in 1978 (Temesgen, 2014).

However, since 1979, the tourism sector was recovered because of relative stability that was seen in the country. Using this opportunity, the government established the Ethiopian Tourism Commission (ETC) supervised by the council of ministers, under proclamation No.182, 1980 in 1979. The main purpose of the Ethiopian Tourism Commissions ( ETC) was "to develop and promote tourism at home and abroad by means of building and expanding accommodation and recreational facilities, to establish and supervise organizations in the business of providing tourist facilities, issue licenses to persons or organizations engaged in the provision of tourist facilities, publicize the tourist attractions of the country, establish administer, expand and control training center for personnel to be engaged in tourist facilities, and prepare and disseminate information concerning tourists. However, the promising habit of tourism was interrupted by the outbreak of the 1984/85 famine and the years of post-famine austerity. The famine brought about a crippling effect on the country's economy, whereby the tourism sector was disproportionally affected. In the mean time, major emphasis was given on rehabilitation and re-construction of the famine victims, let alone tourism development (Birtukan,2018).

The end of military power in 1991 brought about a relative conducive environment attributed to the political 
stability and the market liberalization that attracted a large number of business, conference and vacation tourists. The tourism industry declined following the downfall of Derg due to the destruction of parks as a reflection of the communities opposition against the regime. The surrounding communities cleared forests and parks and converted it to agricultural land and settlements. However, immediately following the transition period, some policy measures were taken, even if recovery of economic losses took a little bit longer. Of particular significance was the declaration of new economic policy under proclamation No. 15/1992. This policy measure made radical shift from command economy to free market which further intensified private investments. Closely linked, Ethiopian Tourism Commission (established by the Derg) was strengthened, to be in charge of tourism investment initiatives, and supervising the establishment and operation of tourism and hospitality facilities, which later transformed into the Ministry of Culture and Tourism. Under this circumstance, one that drew considerable attention was the implementation of decentralization policy, which provides each regional governments of the country an opportunity to develop the tourism potentiality of their respective area. Then after, independently exercised tourism offices in each region was established under proclamation No. 41/1993.68 (Temesgen, 2014).

The country's relative stability, free market economy, and free entry of foreigners despite differences in ideology, religion and race, increase the international tourism market led to the unprecedented rise in the number of international tourist arrivals from roughly 81,581 in 1991 to 139,000 in 1997. However Ethiopia's tourism was challenged between the year of 1998-2000, this was due to the outbreak of the Ethio-Eritrean war for unresolved border dispute with neighboring Eritrea in that period .Therefore, the first sharp decline during this period was seen for the past two years (1998- 2000), when international tourist arrival figures dropped progressively from 139,000 in 1997 to 112,000 in 1998. During 2000 the two countries came into cold peace and the tourism industry was recovered. Following the government obtained assistance from the World Bank and IMF, which offered the government an opportunity to strengthen its efforts on the development of the socio-economic sector. It was the most promising route out of economic deprivation. This laid the foundation for the post-war expansion of tourist travel and the unprecedented rise in the number of tourist arrivals in Ethiopia from 135,954 in 2000 to 148,386 in 2001 source: (Birtukan, 2018).

Figure 1 International tourists' arrivals in Ethiopia during different Ethiopian regime

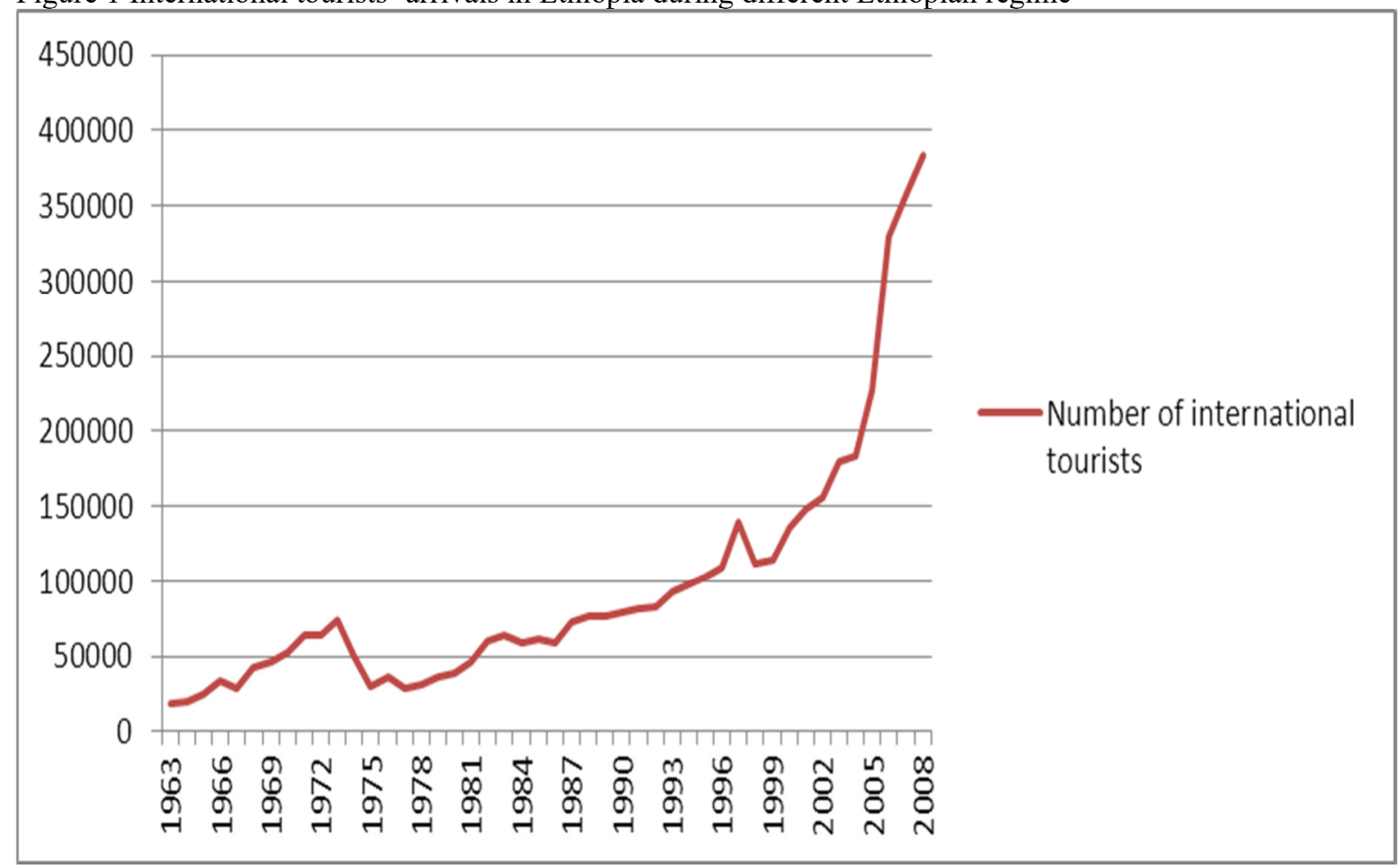

Source: Ministry of Culture and Tourism, (2006)

\subsection{Development of ecotourism in Ethiopia}

Ecotourism is the new concept in Ethiopia and it is difficult to explain its significance accomplishment since the approach of ecotourism is not widely distributed in Ethiopia. The government of Ethiopia also has recognized development and promotion of ecotourism and provided consultancy services for a number of potential developers of ecotourism sites. Although, developers and policy makers do not properly take the idea of ecotourism, the ideas of ecotourism started by investors to involve in development of ecotourism in different regions of Ethiopia. Bishangari Eco-Lodge located at Eastern of Langano Lake in Oromia Region and Village Ethiopia located at Afar 
Region (Bilen) are examples of these private ecotourism developments in Ethiopia (Theodros, 2004). LUPO also aims to create alternative income generating means such as ecotourism to reduce the pressure on the natural resources of land through conducting a pre-feasibility study of proposed areas on the potentials of ecotourism (Scwenk, 2002).

\subsection{Community Based Ecotourism in Ethiopia}

Community Based Eco-tourism is relatively very young in Ethiopia. There are numerous community based ecotourism initiatives and associations doing well all across the country. The specific location of these active Community based ecotourism (CBEs), include; Simien and Bale Mountains national parks, Menze Guassa, Lake Tana, Lalibela Meket in north Wollo (Amahara region) Lake Ziway and Langano, Lake Hawassa, Abune Yossef, Mekedella, Adawa(Tigray region) and Yirgalem, Wonchi Crater Lake (near Ambo, Oromia Region), Adaba Dodola. Although these initiatives are not well integrated in the mainstream tourism marketing, many of these CBEs can be very good models to expand CBEs to the rest of the country as the country is endowed with huge nature-based tourism potential (Sisay,2004) as cited in (Sewnet,2017).

\section{Potential Resource for Community based Ecotourism in Ethiopia}

Ethiopia possesses remarkable tourism potential in its unique and largely unexplored cultural, historical, archaeological and natural resources. Those resources are key to attract visitors and are the basis on which to build a strong tourism industry. With its 3,000 years of history and more than 80 ethnic communities each with their own distinct languages, cultures and traditions'. Scenic, climatic, therapeutic, flora and fauna resources such a unique combination of attractions within a single country has no match on the African continent (MOCT, 2006).

The country has abundant parks and reserves to shelter its flora and fauna. Community based Ecotourism represents an approach to tourism that emphasizes on environmental and cultural preservation. It highlights opportunities for tourists and other visitors to experience aspects of the country's ecology and natural attractions as well as unique features of its archaeology, history and culture. The following category specifies the major community-based Ecotourism potentials in Ethiopia (MOCT, 2006). Different heritages of Ethiopia have been registered as world heritage sites by United Nations Economic, Social and Cultural Organization (UNESCO), namely Simien MountainNational Park (1978), Rock-hewn Churches of Lalibela (1978), Fassil Ghebbi (1979), Lower Valley of the Omo (1980), Axum (1980), Tiya (1980), Lower valley of the Awash (1980) and the fortified Historical town of Harar,(Oromo Gada system ) Timket festival, Fiche chambalala

Ethiopia has many attractive mountains like The Bale and Semien Mountains, mountains in wag and lasta, Northeastern Tigrai the Irob region, Chilalo Mountains in Arsi, Ziquala peaks and Fantalle in Awash national park ,these places are best suitable for individual trekkers, hiking parties and for professional climbers. Ethiopia's lakes such as Abijata shala, Rift valley, Wenchi, Hawasa have varied features of great interests to Eco tourists: these includes: birds, wildlife, vegetation, colorful ethnic groups, historic churches and monasteries, unusual geologic features and much more. Extensive and nice looking Ethiopia's national parks, like Nechsar, Mago, Omo, Awash, Bale mountain,semien mountain,chebera cherchora, yangudi rassa ,Nechsar, gambela, maze, kafta shiraro, etc and wild life sanctuaries such as sankele (Swaynes heartbeest), Babile (elephant), kuni muktar(mountain nyala), Didessa,yabelo,Stephanie are spectacular places for Eco tourists to watch the real African big wild life and enjoy the breathtaking surrounding landscapes. The underground cave and rock arts of Sof Omer in Bale, Lega goda at the vicinity of Dire dawa, Shebe found at a short distance from Dila town are places to admire the works of nature, rock paintings and carvings of people and animals. Battle sites like Adowa and Maqdala and places of significant political events like Boru Meda, Entoto, and Ankober etc are most interesting sites for history loving Eco tourists.different historic site like: shek hussien shrine, aksum oblesskis, roch hewan church of lalibela, are some of the potential site that our country have for community based ecotourism (Henze, 2007).

Ethiopia is renowned for its traditional festivals that in most cases reproduce traditions that have been maintained for centuries. The following are the most important:

$\checkmark$ Timket: Ethiopian Epiphany (January)

$\checkmark$ Gena: Ethiopian Christmas in Lalibela (January)

$\checkmark$ Meskel: the finding of the True Cross (September) listed as Intangible World Heritage by UNESCO in 2013

$\checkmark$ Thanksgiving to the Oromo supreme God "Waqa" annually at Hora (Lake Arsedi) in Bishoftu Town during the first week of October

$\checkmark \quad$ Sidama Nation New Year Festival

$\checkmark$ Ethiopian Nations, Nationalities and Peoples Day; the event to experience Ethiopia on one stage (December)

$\checkmark$ Ashenda and Shaday in Tigray and Amhara regions, respectively

$\checkmark$ Ashura in Harar are some of the basis for community-based ecotourism development in Ethiopia. 


\section{Challenges of Community Based Ecotourism in Ethiopia \\ 4.1. Conflict of interest over resource usage}

Conflict is the major challenge for developing community-based ecotourism, in Ethiopia, for instance in the Awash Park area. The Park management faces the inter ethnic conflict between Kerreyu, Ittu and Afar pastoralists for the traditional resource ownership rights of dry season grazing and access to water points. Particularly, a prolonged drought usually worsens the conflict between these rival groups. Conflict with the Park scouts and the local Pastoralist is usual in the park. Employees of the Park are also under big threat. Since the majority of the Park area is out of control of the Park administration, most of the time ethnic groups used the core wildlife area inside the Park as a battle field which usually resulted wildlife habitat destruction, wildlife killing and migration. Hence the Park is unable to ensure the safety of tourists within the protected areas. The threat of being robbed while visiting or traveling to the Park reduced the number of international and domestic visitors alike. Thus, security related concerns are big challenges to develop Community Based Ecotourism (CBET) in such area (Alamayew, 2011).

(Bires ,2014) in his study revealed that there was a serious ownership problem between the church communities and the government, particularly the Banja Woreda Culture and Tourism Office. Inline with this , (Ketema ,2015) also found that there was a conflict of interest on the ownership of Wonchi Crater Lake which is situated in Oromia Regional State, in central Ethiopia. In addition, (Ambelu ,2011) in his study in Meket Wollo, Amhara Region in Northern Ethiopia, identified land ownership issues as challenge for the development of community lodges in some of the ecotourism sites.

\subsection{Lack of Cooperation among Stakeholders}

Lack of stakeholder's integration is one of challenges for Community Based Ecotourism development in different parts of Ethiopia and also globally. For instance, (Ambelu ,2011) revealed that a lack of cooperation and a solid formal relationship between the community tourism enterprises and other stakeholders was identified as a 'bottleneck' in the study area. Similarly (Berhanu ,2013), in his study at Alatish National Park, identified weak integration among different stakeholders and the park office as abottleneck for community-based ecotourism development. Berhanu stated that the buffer zone of the park was managed only by the North Gondar Natural Resource Management office without integrations with the park office, and moreover, the Justice Office considers criminal cases such as illegal hunting, fishing and other unsustainable resource utilization as minor cases and sometimes such cases are left to gap without either any formal sanction or penalty in evidence. In other studies, (Alemayehu ,2011 and Aynalem ,2013) have also reported a lack of stakeholder cooperation as a m,ajor obstacles for community-based ecotourism development in their study areas.

\subsection{Lack of awareness and limited participation}

In developing countries like Ethiopia, Lack of awareness and experience of local community, limit the understanding of potential impacts of tourism development, lack of awareness and experience may hesitate community capacity to benefit from tourism development opportunities.Community based ecotourism development encourages a local community's participation and they also benefit in sharing activities, and also enhance their understanding about the natural and cultural resource conservation initiatives. However, most of ecotourism destinations in Ethiopia are not in line with the principles of community-based ecotourism. Most of the local people had no awareness about ecotourism in general and community-based Ecotourism in particular, and they did not participate at any stage in park management decisions (Alemayehu, 2011). Similarly,( Demeke and Verma 2014), in their study in the Bale Mountains National Park, found that respondents did not participate in any ecotourism activities although they wished to participate, which could be attributed to the limited flow of tourists in the study area.

\subsection{Lack of basic ecotourism infrastructure and facilities}

Basic ecotourism facilities such as accommodation, transportation, health services and other support facilities are essential to enhance the satisfaction of eco tourists and to maximize the length of stay of tourists to any area. However, the findings of this review indicated that most of the ecotourism destinations in Ethiopia are devoid of these facilities and services. For instance, (Ketema ,2015) stated that there is a dire absence of well-designed trekking passes, parking facilities, camping sites and effective land use planning alongside the lake. Ketema has also mentioned that there is a lack of transportation and comfortable roads, and there are no eco- lodges andcatering facilities around the lake. Similarly, (Eshetie ,2012) also stated that a lack of basic facilities such as electricity, an effective road network to and from Borena Sayint National Park and health stations, are other major problems encountered. (Bires ,2014) in his study of Lake Zegena in Amhara Regional state, revealed a shortage of sufficient potable water, a lack of electricity, toilets and other important facilities that tourists require to make their trips memorable.

Furthermore, (Berhanu ,2013) has also reported that poor health and accommodation services, very limited 
shopping, banking and postal services, the absence of all-weather roads, and no telecommunication service in all kebeles of Quara wereda except Gelegu town, are all huge problems requiring urgent support. (Demeke and Verma ,2014 and Alemayehu, 2011) also identified limited transportation and accommodation facilities as a challenge for CBET in their study area. (Alemayehu ,2011) asserts that the community has an acute shortage of clean water and local people who reside adjacent to the park are forced to use the irrigation canal for themselves and for their livestock. (Ayinalem ,2013) also revealed that tourism infrastructure like accommodation establishments, road transportation, and other destination facilities and services are very poor and limited in number in his study areas.

\subsection{Lack of trained manpower}

Lack of skilled human resources is the major challenges facing the tourism industry in the country. The country has, for instance, a limited number of institutions offering tourism training programmes both at the graduate and post graduate levels and at the certificate and diploma levels (World Bank, 2006). Tourism professional plays a vital role for the development of ecotourism site since they can know how to plan and organize tourism initiatives in effective manner. (Alemayehu ,2011), on his study at Awash national park. pointed out that there was no ecotourism expert or consultant who was in charge of ecotourism or community-based ecotourism activities in Awash National Park as a result tourism aspect were not well managed. (Bires, 2014) also stated a shortage of tourism professionals in his study area.(Ambelu ,2011) also reported that at District/woreda level, culture and tourism offices have only three staff where the manager is possibly working on the political issues while the rest, namely two employees, are responsible for a collection of works found in the office and the poor qualifications of the staff is also a big challenges for CBET development of the study area.

\section{SUMMARY AND CONCLUSIONS}

This review attempts to examine the potentials and challenges of Community Based Ecotourism development in Ethiopia. The review showed that Ethiopia has huge attractive natural and cultural potential resource needed for community-based ecotourism development. These includes historical, cultural, archaeological, anthropological, scenic, climatic, therapeutic, flora and fauna resources and lakes that is source of fish species, , cultural food and drink of local community, traditional festivals are valuable opportunities that empower development of community based ecotourism, However having these potential resource community- based ecotourism development is constrained in Ethiopia due to the following factors:

$\checkmark \quad$ Lack of community knowledge about community-based ecotourism

$\checkmark$ Limitations in community capacity building from government organizations

$\checkmark$ Lack of community social infrastructures that had lead local community to destructions potential resource of study area.

$\checkmark \quad$ Lack of promotions of the study area potential resource for tourism

$\checkmark \quad$ Lack of cooperation's among community and governmental and private organizations to are the obstacles that hinders development of community based ecotourism in Ethiopia.

\section{Future work of line}

* It has to have broader awareness creation program for the wider communities towards the tourism business and its impacts on their lives by providing adequate trainings.

* To ensure community-based ecotourism in Ethiopia, local communities must undergo various capability-building programs.

* Local community social infrastructural service should be provided in order to reduce community dependence on Natural resources.

* A further investigation is needed to identify and promote potential resource of community-based ecotourism

\section{REFERENCES}

Alemayehu, D. (2011). Challenges and Opportunities for the Establishment of Community- based Ecotourism in the Awash National Park Area, Unpublished thesis, Addis Ababa University.

Ambelu, G. (2011). Practices, Challenges and Opportunities of Community Based Ecotourism Development in Meket Woreda North Wollo; Unpublished Thesis Addis Ababa University

Aynalem, S. (2013). Tourism Potentials and Community-Based Ecotourism Development, a Case of Choke Mountain and its Environs, Ethiopia, Journal of Hospitality and Management Tourism, 6, (4).

Baker, N. (2008). Sustainable wetland resource utilization of Sango Bay through ecotourism development. African J. Environ. Sci. and Technol., 2(10): 326-335.

Berhanu, K. (2013). Opportunities and Challenges for Wildlife Conservation and Ecotourism Development of Alatish National Park; Northwest Ethiopia; unpublished thesis, University of Gondar. 
Bires, Z. (2014). Challenges and Prospects of Community Based Ecotourism Development In Lake Zengena, BanjaWoreda, Awi Nationility Administration; unpublished thesis, Addis Ababa University.

Birtukan,A. (2018). Atinkut pitfalls of tourism development in ethiopia: a case of bahir dar town and its surroundings, a historical perspective, Vol.6, No.1, pp.11-28.

Demeke, A. \& Ashok, V. (2013). Local attitude towards environmental conservation and ecotourism in BMNP, Journal of Environmental Science and Water Resources, 2(8)

Denman, R. (2001). Guidelines for community-based ecotourism Development: World Wide Fund for Nature, Gland, Switzerland.

Eshetie, W. (2012). Potentials, Challenges and Opportunities for Community Based Ecotourism Development at Borena Sayint National Park; South Wello, Unpublished thesis University of Gondar.

Henze BP (2007b). Ecotourism in Ethiopia: Opportunities and ideas. Conference of IDR/AAU. Retrieved from www.irrrob.org/ecotourism-inethiopia.html on November 28,2017.

Hipwell, W.T. (2007). Taiwan Aboriginal Ecotourism: Tanayiku Natural Ecology Park. Annals of Tourism Research, 34 (4) 876-897.

IUCN, (1994). Guide to the Convention on Biological Diversity. IUCN, Gland, Switzerland, Cambridge University, UK.

IUCN ,(1996). World conservation, Special issue on collaborative management, NO-2.

Ketema, D. (2015). Challenges and prospects of community-based ecotourism Development in Wenchi Crater Lake, Ambo, Journal of Hospitality and Tourism Management, 6 (4).

Kiss, A. (2004). Is community-based ecotourism a good use of biodiversity conservation funds? TRENDS in Ecology and Evolution. 19(5): 232-236.

Lowmen, M. (2004). "Ecotourism and its impact on forest conservation." Action Bioscience; American institute of Biological Sciences.fromwww.actionbioscience.org. Accessed on october27,2017.

Mitchell, J. and Muckosy, P. (2008). A Misguided Quest: Community-Based Tourism in Latin America. London: Overseas Development Institute.

MOCT, (2006). Ministry of Culture and Tourism of Ethiopia.Unpublished: Tourism statistics bulletin No.8.

Neto, F. (2002). Sustainable tourism, environmental protection and natural resource management: paradise on Earth? Retrieved from http://www.mtnforum.org. Accessed on October 15,2017.

Sewnet, T.(2017). Challenges and Opportunities for Community Based Ecotourism Development in Ethiopia. African Journal of Hospitality, Tourism and Leisure, Volume 6 (3)

Sisay, A. (2004). Adaba-Dodola community- based ecotourism development. Retrieved fromwww.inno.forest.org/files/orig.html [Accessed on 18 November,2017.

Temesgen, K. (2014). The Tourism Industry in Ethiopia. Mekelle University, Ethiopia

The International Ecotourism Society, (2012). Ecotourism development; Retrieved from website http//www.ecotourism.org, 27th september, 2017.

United Nations, (2001). UNEP manual for the international year of ecotourism. pp. 1-18. Retrieved from www.uneptie.org/tourism/home/html: United Nations Environment Program.

World Bank, (2006) Ethiopia in Makeda's Footsteps: towards a strategy for pro-poor tourism development. World Bank Report No. 38420-ET

Theodros Atlabachew. (2002). Sustainable Tourism Development. Paper presented on the tourism Symposium on Occasion of the World Tourism Day, Sheraton Addis, September 24.

Scwenk, T. (2002).Potentials for Community Based Eco-Tourism Project in the Area of the Wenchi and Dendi Crater Lakes. Unpublished Paper, for community based eco-tourism studies, West Shewa, Oromia Region, Ethiopia 